\title{
PEMBINAAN PERCAKAPAN BAHASA INGGRIS BAGI MASYARAKAT PERUMAHAN GRIYA BATU AJI ASRI BATAM
}

\author{
Winda Evyanto \\ Universitas Putera Batam (UPB), Batam, Indonesia \\ e-mail: Winda731016@yahoo.com \\ Zia Hisni Mubarak \\ Universitas Putera Batam (UPB), Batam, Indonesia \\ e-mail: mubarakzia@gmail.com \\ Yulia Puspita Sari \\ Universitas Putera Batam (UPB), Batam, Indonesia \\ e-mail: Yulia310796@gmail.com
}

\begin{abstract}
English is language that is spoken widely around the world. One of example where English is widely spoken around the country is in Singapore. Not only this country, the neighborhood country such Malaysia has more people who can speak English fluently. For both countries, English is official and second language. While the other neighborhood country such Indonesia uses English less frequently than the national language, Bahasa Indonesia. English is still a foreign language for Indonesian. By looking at this phenomenon, people in our neighboring countries such Singapore and Malaysia use English for their daily conversation. When they want to go to Indonesia, especially to the nearest island from both countries; that is Batam island, sometimes they face that some people in Batam cannot communicate well using English. It happens when they go to some urban areas such as Batu Aji in Batam city. The team of lecturer conducts an activity to the people from an urban area in Batu Aji to be given a community service to teach team how to speak better daily English conversation. The activity is started by training the people vocabulary through the flash card activity. From this activity, people from Griya Batu Aji resident show a good enthusiasm to join the activity to train them better in speaking. This activity is a continuous activity where the team reports the first phase progress of the activity only in this article.
\end{abstract}

Keywords_English speaking, vocabulary, flash card

\section{PENDAHULUAN}

ulau Batam adalah salah satu pulau yang paling luar dari sekian ribu pulau yang ada di Indonesia. Meskipun demikian pulau Batam memiliki letak yang sangat strategis bila dilihat dari letaknya karena berbatasan langsung dengan 
dua Negara tetangga yaitu Singapura dan Malaysia. Karena letak yang strategis ini Batam disebut juga sebagai pintu gerbang utama Indonesia bagi warga Negara Singapura dan Malaysia yang ingin berkunjung ke kota Batam. Sudah tidak asing lagi bahwa warga kedua Negara sangat sering berkunjung ke pulau Batam terutama untuk alasan bisnis, bekerja pada perusahaan multinasional, dan sekedar menghabiskan akhir minggu. Tidak dapat dipungkiri bahwa kedatangan wisatawan dari kedua Negara tetangga tersebut bersentuhan langsung dengan perekonomian dan masyarakat Batam. Maka dengan alasan ini dapat ditarik sebuah permasalahan yang muncul yaitu pada penggunaan bahasa asing seperti bahasa Inggris.

Seperti diketahui bersama bahwasanya warga Negara Singapura menggunakan bahasa Inggris sebagai bahasa resmi Negara tersebut disamping bahasa kedua mereka seperti bahasa Mandarin, Tamil dan Melayu, sedangkan warga Negara Malaysia menggunakan bahasa Inggris sebagai bahasa kedua mereka dan bahasa Melayu adalah bahasa resmi Negara Malaysia. Sehingga dapat dikatakan bahwa warga dari kedua Negara tetangga tersebut sudah terbiasa dengan penggunaan bahasa Inggris. Ketika mereka berkunjung ke kota Batam, mereka sebenarnya tidak terlalu kesulitan dalam berkomunikasi dengan menggunakan bahasa Melayu, namun beberapa padanan kata tidak dapat dijelaskan dengan mudah dari bahasa Melayu ke bahasa Indonesia, sehingga mereka menggunakan bahasa Inggris. Bagi sebagian lagi yang tidak bisa berbahasa Melayu, mereka menggunakan bahasa Inggris secara utuh dalam kesehariannya. Fenomena inilah yang kemudian muncul sebagai suatu masalah dimana ketika mereka mendatangi tempat-tempat wisata atau berbelanja ke daerah-daerah pinggiran kota seperti daerah Batu Aji di kota Batam, didapati kebanyakan masyarakat pada daerah ini masih terkendala dalam penggunaan bahasa. Dalam kesempatan lain Arianto (2019) menemukan bahwa kemampuan berkomunikasi bahasa Inggris pelaku usaha pariwisata di pantai Setokok belum cukup memadai, sehingga perlu dilaksanakan pelatin berkala dalam mendukung upaya pemerintah dalam menggalakkan dunia pariwisata di kota Batam.

Bahasa inggris merupakan bahasa percakapan yang paling banyak diucapkan di dunia ini sehingga membuatnya menjadi bahasa Internasional yang paling utama. Kemanapun seseorang akan pergi, jika dia mampu berbahasa Inggris, maka dia tidak akan menemukan banyak kesulitan. Walaupun berada di Negara dengan penduduk yang tidak berbahasa Inggris sekalipun, mereka dapat mendatangi pusat-pusat informasi seperti di kantor pemerintahan setempat yang biasanya menyediakan tenaga-tenaga yang terampil dalam berkomunikasi dengan menggunakan bahasa Inggris. Menguasai bahasa Inggris menjadi sebuah keharusan yang sangat mendasar dalam menghadapi perkembangan zaman dan pesatnya teknologi informasi.

Pada tahun 2015, masyarakat ASEAN dihadapkan oleh berlakunya Masyarakat Ekonomi ASEAN (MEA) dimana arus informasi antara Negara ASEAN sudah tidak terbatas oleh jarak lagi. Banyak kerjasama yang baik antara Negara ASEAN dan berimbas kepada sumber daya manusia di setiap Negara seperti halnya kerjasama dalam pengembangan ekonomi masyarakat seperti peningkatan perdagangan antara Negara anggota ASEAN (Araminta \& Halimi, 2015; Waterworth, 2016). Jika setiap Negara tidak membekali warganya dengan daya saing yang cukup maka akan terganti dengan sumber daya manusia dari Negara lain. Sehingga disini kita memandang begitu pentingnya masyarakat untuk menguasai bahasa internasional sebagai bahasa percakapan dunia luas yaitu bahasa Inggris. Dengan menguasai bahasa Inggris diharapkan daya saing 
warga Negara Indonesia khususnya dalam kancah Internasional seperti MEA akan semakin meningkat.

Oleh karena itu tim pengabdi berinisiatif untuk mengajarkan Bahasa Inggris yang digunakan untuk percakapan sehari hari kepada masyarakat di kota Batam khususnya yang tinggal di daerah kecamatan Sagulung tepatnya di RT 01 RW 016 perumahan Griya Batu Aji Asri. Tim pengabdi memilih tempat ini karena setelah melakukan survei banyak ditemukan warga RT 01 RW 016 yang tertarik untuk mempelajari bahasa Inggris. Hal ini disebabkan karena banyak diantara warga yang bekerja pada perusahaan asing yang juga dikelola oleh orang asing. Jadi untuk berkomunikasi dengan menggunakan bahasa Inggris, mereka masih sering tidak percaya diri. Dengan diadakannya pelatihan ini maka warga RT 01 RW 016 merasa terpacu untuk menguasai bahasa Inggris dan mampu berkomunikasi dengan lebih baik menggunakan bahasa asing tersebut. Dalam pelatihan ini tim pengabdi memfokuskan kepada kemampuan dalam berkomunikasi seperti memperkenalkan diri dan percakapan sehari-hari.

Tim pengabdi kemudian juga menggunakan salah satu media pembelajaran bahasa Inggris yang menarik yaitu dengan menggunakan media pembelajaran kartu atau yang sering dikenal dengan istilah flash card. Media pembelajaran kartu ini sebenarnya bukan sesuatu yang asing bagi pembelajar karena dapat ditemukan dalam kehidupan sehari-hari. Bentuknya juga bermacam-macam dimulai dari ukurannya yang beragam sesuai dengan jenis dan kebutuhannya. Media flash card ini dapat menjadi alternatif pembelajaran yang menarik baik bagi pembelajar muda dari tingkat sekolah dasar hingga ke pembelajar dewasa. Adapun bentuk flash card yang menarik dapat dilihat pada contoh di bawah ini:

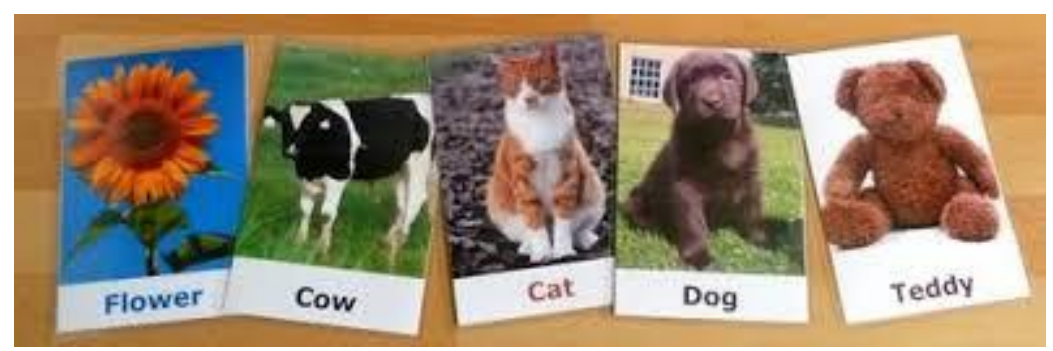

Gambar 1 Contoh flash card kosakata bahasa Inggris

Media flash card dapat juga di buat dengan menggunakan desain sendiri sesuai dengan kreatifitas masing-masing. Tidak ada batasan dalam membuat flash card yang baik. Artinya, batasan tersebut hanya pada imajinasi masing-masing. Media pembelajaran flash card ini terbukti dapat meningkatkan hasil belajar berbagai bidang ilmu termasuk pembelajaran bahasa (Astami, 2010; Febriyanto \& Yanto, 2019; Hotimah, 2010; Kusumawati \& Julianto, 2015; Maghfiroh, 2013; Mulyani, 2017; Munthe \& Sitinjak, 2018). Tidak hanya itu, media pembelajaran kartu ini juga membuat peserta belajar semakin tertarik untuk belajar karena terdapat kata dan gambar, sehingga akan membuat peserta lebih mudah mengingat tentang kosakata dengan lebih optimal. Berdasarkan uraian tersebut di atas tim pengabdi tertarik untuk memberikan pelatihan dengan judul "Pembinaan Pelatihan Bahasa Inggris untuk Percakapan Warga RT 01 RW 16 Perumahan Griya Batu Aji Asri Kelurahan Sungai Langkai Kecamatan Sagulung Batam". 


\section{METODE}

Sebelum melaksanakan pengabdian, tim pengabdi melakukan survei ke lokasi penelitian yaitu perumahan Griya Batu Aji Asri khususnya ke RT 01 RW 016 kelurahan Sungai Langkai kecamatan Sagulung. Berdasarkan survei tersebut ditemukanlah beberapa permasalahan atau kendala yang dihadapi warga. Tim pengabdi menyimpulkan permasalahan yang dihadapi adalah seperti rasa percaya diri yang rendah dan kurangnya pengetahuan warga pada lokasi pengabdian dalam hal berkomunikasi dengan menggunakan bahasa Inggris melalui percakapan yang paling sederhana sekalipun. Kendala lainnya yang dihadapi dalam pembelajaran bahasa Inggris adalah teknik pembelajaran yang monoton dan kurang diminati oleh peserta.

Pelaksanakan kegiatan pembinaan dan pelatihan berbicara dengan menggunakan bahasa Inggris baik teori dan praktik disesuaikan dengan keadaan serta kebutuhan peserta pelatihan. Untuk mengukur sejauh mana tingkat kebutuhan para peserta, maka tim pengabdi memberikan sejenis pre-test berupa interview sederhana dengan menggunakan bahasa Inggris untuk mengetahui kemampuan bahasa Inggris masyarakat. Setelah diberikan tes awal, tim pengabdi kemudian memberikan pelatihan berkomunikasi dengan menggunakan bahasa Inggris sederhana sebagai dasar dalam percakapan sehari-hari bagi peserta kegiatan pengabdian.

Adapun langkah-langkah dalam pelaksanaan pengabdian ini adalah dengan menyiapkan berbagai peralatan dan kebutuhan non-teknis lainnya seperti flash card, foto kopi materi, papan tulis, tempat belajar dan lain sebagainya. Tim pengabdi kemudian menjelaskan tujuan pengabdian agar peserta pengabdian mengerti tujuan pelaksanaan kegiatan ini. Selanjutnya tim pengabdi menyiapkan beberapa kata atau istilah yang jarang digunakan dengan menggunakan media pembelajaran flash card. Tim pengabdi kemudian secara bergantian melatih terlebih dahulu kosakata bahasa Inggris dengan cara melafalkan kata-kata tersebut untuk diikuti oleh peserta kegiatan. Selanjutnya, tim pengabdi memberikan contoh penggunaan kata-kata tersebut dalam kalimat sederhana dengan melafalkan sesuai dengan pengucapannya, peserta juga tetap diminta untuk berpartisipasi dengan cara mengulang kalimat yang telah dilafalkan oleh tim pengabdi. Selanjutnya kegiatan dilakukan secara berpasangan dimana peserta diminta untuk menciptakan komunikasi dua arah sederhana seperti perkenalan, bertanya, menjelaskan dan lain sebagainya. Pada akhir kegiatan peserta akan diberikan asesmen secara langsung oleh tim pengabdi yaitu dengan memberikan pertanyaan sebagai salah satu bentuk percakapan sederhana.

\section{HASIL DAN PEMBAHASAN}

Peserta kegiatan yang datang pada kegiatan pengabdian ini adalah warga perumahan Griya Batu Aji Asri RT 01 RW 016 kelurahan Sungai Langkai kecamatan Sagulung Batam. Antusiasme warga sangat tinggi dalam hal mengikuti kegiatan ini. Beberapa alasan yang dikemukakan seperti mereka ingin menguasai bahasa Inggris baik komunikasi dan tertulis dikarenakan alasan pekerjaan. Ada juga peserta yang menganggap bahwa menguasai bahasa Inggris itu penting karena ingin mencontohkan kepada anak-anaknya dan dapat memotivasi mereka agar serius ketika belajar bahasa Inggris di sekolah ataupun di tempat kursus. Tim pengabdi tidak membedakan peserta baik bapak-bapak 
dan ibu-ibu serta beberapa pemuda setempat. Tim pengabdi hanya focus kepada tujuan yang telah ditetapkan sebelumnya. Dari hasil tes awal peserta kegiatan dengan memberikan pertanyaan langsung didapati bahwa kemampuan rata-rata peserta masih berada pada tingkat yang sangat rendah. Hal ini terjadi karena beberapa faktor seperti kurangnya rasa percaya diri dalam diri mereka untuk belajar bahasa Inggris dan menganggap bahasa Inggris ini adalah bahasa yang rumit. Ada juga peserta yang kemudian menyampaikan bahwa ketika sekolah dulu gurunya killer sehingga apapun yang diajarkan tidak pernah masuk ke ingatan.

Hal pertama dalam memberikan penanganan pada rendahnya kemampuan bahasa Inggris mereka adalah dengan mengingat kembali kosakata yang pernah mereka pelajari dulu misalkan kata-kata dalam ruang lingkup sehari hari yaitu market, go, fruit, dan banyak lagi. Tim pengabdi memberikan perlakuan yaitu dengan menerapkan media pembelajaran yang menarik dengan menggunakan media flash card. Tim pengabdi kemudian menunjukkan gambar yang ada di media flash card dan meminta mereka mengingat kosakata dari gambar yang dilihat. Tim pengabdi kemudian mengoreksi apabila terdapat kesalahan dengan membalikkan media flash card yang di belakang kartu bergambar tersebut terdapat kata dalam bahasa Inggris. Peserta diminta satu persatu untuk menyebutkan kata-kata tersebut dan mengikuti pelafalan yang benar yang diucapkan oleh tim pengabdi. Begitu seterusnya kegiatan dilakukan untuk men-drill peserta dengan menggunakan kosakata yang didapat dari media flash card.

Setelah peserta mendapatkan sedikit pencerahan dan penyegaran pikiran mereka dengan mengingat ulang kembali kosakata yang dahulu mungkin terlupa, maka tim pengabdi kemudian memberikan contoh-contoh percakapan sederhana kepada para peserta. Tim pengabdi meminta peserta untuk mengikuti pelafalan kalimat percakapan sederhana dan kemudian mempraktekkannya dengan peserta lainnya. Tim pengabdi tidak memberikan batasan kepada para peserta untuk berimprovisasi dalam menciptakan kalimat-kalimat yang berhubungan dengan percakapan sederhana. Adapun beberapa contoh kalimat yang diberikan kepada peserta adalah sebagai berikut:

A: Hi B, are you going to the market?

B: Yes. Want to join me?

A: I can't. I still have something to do with my motor cycle. Could you help to buy some fresh carrots for me?

B: Oh, no problem. Ho much do you want?

A: 2 kilos please. Thanks $B$.

B: Never mind.

Peserta kegiatan kemudian tidak dibatasi untuk mengembangkan percakapan sederhana ini sesuai dengan konteks dan pengetahuan yang mereka miliki. Tim pengabdi juga memberikan tantangan kepada peserta untuk dapat mempraktekkan percakapan yang mereka latih tanpa menggunakan dialog yang sudah disediakan sebelumnya. Dalam hal ini, peserta diminta untuk melakukan pengembangan seluas mungkin. Hal ini bertujuan untuk meningkatkan kemampuan peserta dalam berkomunikasi dan meningkatkan rasa kepercayaan diri masing-masing individu peserta kegiatan. Adapun jalannya kegiatan pengabdian kepada masyarakat ini dapat dilihat pada gambar 2 . 


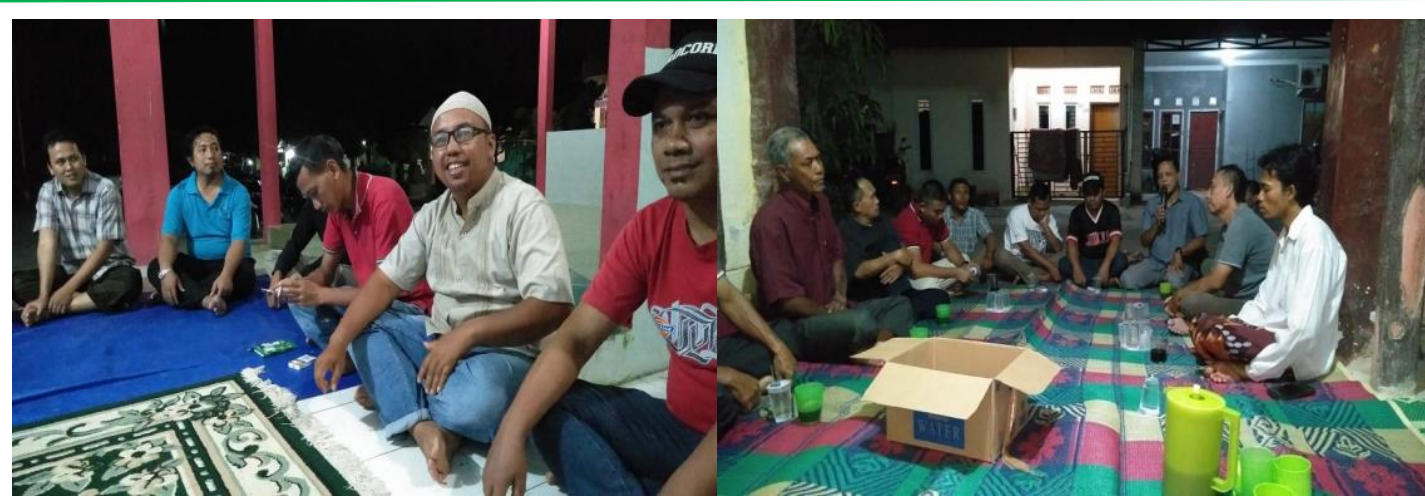

Gambar 2 Foto kegiatan Pengabdian

Setelah semua rangkaian kegiatan pengabdian dilaksanakan, maka tim pengabdi kemudian asesmen kecil untuk melihat apakah kegiatan pengabdian ini memberikan dampak yang lebih baik bagi peserta kegiatan ini. Jika di awal kegiatan tim pengabdi mengambil tes awal, maka di akhir kegiatan tim pengabdi juga mengambil tes akhir yang fungsinya adalah untuk mengukur ketercapaian dalam proses pembelajaran. Tes yang dilakukan adalah tes yang berkaitan dengan pertanyaan terhadap materi yang telah dipelajari yaitu seputar kosakata dan berkomunikasi sederhana. Dalam hasil tes menunjukkan bahwa ada perubahan terhadap pola peserta kegiatan yang tadinya merasa kurang percaya diri menjadi lebih percaya diri dikarenakan mereka memiliki pengetahuan tentang bagaimana melafalkan kata-kata dalam bahasa Inggris. Ditemukan juga bahwa dengan melatih terus menerus kegiatan berkomunikasi, maka peserta akan semakin terbiasa menggunakan bahasa Inggris. Sehingga secara umum dapat disimpulkan kegiatan ini memberikan manfaat bagi peserta pelatihan. Namun, kekurangan pada kegiatan ini kemudian muncul yaitu pada keberlangsungan kegiatan ini secara terus menerus dimana tim pengabdi memiliki keterbatasan waktu begitu juga peserta kegiatan yang rata-rata juga bekerja. Dengan ini tim pengabdi berharap kegiatan serupa dapat terus dilakukan baik oleh tim pengabdi sendiri maupun oleh tim-tim pengabdi lainnya.

\section{KESIMPULAN}

Setelah kegiatan pengabdian kepada masyarakat dilaksanakan oleh tim pengabdi didapati bahwa kegiatan pengabdian ini memberikan dampak yang positif bagi proses pembelajaran secara menyeluruh. Nampak dari hasil pengabdian bahwa kegiatan ini menimbulkan rasa antusias yang tinggi dari peserta kegiatan dan mendapatkan respon serta feedback yang sangat berharga bagi perbaikan kualitas mengajar tim pengabdi ke depannya. Dengan adanya kegiatan pengabdian ini peserta merasa bahwa kegiatan semacam ini sangat memberikan motivasi dan rasa percaya diri yang kuat bagi setiap individu akan pentingnya bahasa dalam kehidupan dunia modern dan dalam menghadapi arus globalisasi yang semakin pesat. Dari kegiatan pengabdian ini juga didapati bahwa penggunaan media pembelajaran yang menarik dan interaktif salah satu contohnya seperti penggunaan media flash card dapat membantu meningkatkan daya ingat dan hasil belajar. Begitu juga dengan proses drill yang diberikan dapat menjadikan peserta percaya diri dalam melafalkan kata-kata dalam bahasa Inggris. 


\section{SARAN}

Kegiatan pengabdian ini tentu masih jauh dari kata sempurna. Hal ini disebabkan oleh keterbatasan waktu yang dimiliki oleh tim pengabdi dan peserta serta cakupan peserta kegiatan yang masih terfokus pada salah satu daerah saja. Sehingga hasil kegiatan ini tidak dapat digeneralisasikan sebagai sebuah hasil yang pasti pada satu daerah yang lebih luas. Namun hasil kegiatan ini dapat mencerminkan dan menjadi tolak ukur dalam memetakan kemampuan penggunaan bahasa Inggris oleh masyarakat kota Batam dalam menghadapi pesatnya perkembangan teknologi dan informasi. Disarankan juga kepada pemangku kepentingan agar dapat mengambil masukan dari hasil kegiatan ini untuk pengembangan pendidikan menjadi lebih baik di masa depan.

\section{DAFTAR PUSTAKA}

Araminta, L. D. W., \& Halimi, S. S. (2015). ASEAN Economic Community 2015: Needs analysis of Universitas Indonesia's engineering students. Indonesian Journal of Applied Linguistics, 5(1), 11-18. https://doi.org/dx.doi.org/10.17509\%2Fijal.v5i1.841

Arianto, T. (2019). Pembinaan Peningkatan English Conversation Di Pantai Setokok Indah Setokok. PUAN Indonesia, 1(1), 10-18. Retrieved from http://idebahasa.or.id/puanindonesia/index.php/about/article/view/2

Astami, T. S. (2010). Efektifitas penggunaan media flashcard dalam pengajaran Kakikata to Yomikata III pada mahasiswa Ubinus semester tiga tahun ajaran 2010/2011. Lingua Cultura, 4(2), 183-190.

Febriyanto, B., \& Yanto, A. (2019). Penggunaan media Flash Card untuk meningkatkan hasil belajar siswa. Jurnal Komunikasi Pendidikan, 3(2), 108-116.

Hotimah, E. (2010). Penggunaan media flashcard dalam meningkatkan kemampuan siswa pada pembelajaran kosakata bahasa Inggris kelas II MI Ar-Rochman Samarang Garut. Jurnal Pendidikan Universitas Garut, 4(4), 10-18.

Kusumawati, S., \& Julianto. (2015). Pemanfaatan media flash card untuk meningkatkan hasil belajar IPA pada siswa di sekolah dasar. JPGSD, 3(2), 1649-1659.

Maghfiroh, L. (2013). Penggunaan media flashcard untuk meningkatkan hasil belajar IPS pada pembelajaran tematik di sekolah dasar. JPGSD, 1(2`), 113.

Mulyani, S. (2017). Penggunaan media kartu (flash card) dalam meningkatkan hasil belajar konsep mutasi bagi peserta didik kelas XII. Jurnal Profesi Keguruan, 3(2), 143-148.

Munthe, A. P., \& Sitinjak, J. V. (2018). Manfaat serta kendala menerapkan flashcard pada pelajaran membaca permulaan. JDP, 11(3), 210-228.

Waterworth, P. (2016). Teaching English in ASEAN: The voices of English teachers in ASEAN nations. Indonesian Journal of Applied Linguistics, 5(2). https://doi.org/10.17509/ijal.v5i2.1340 